\title{
The Innovation of Basa Sardine Sticks to Optimize Social Economic on Puger Society
}

\author{
Rully Putri Nirmala Puji, Indah Suci Bunga Lestari, Ilvatus Safiroh, Sri Indah Rahayu
}

University of Jember, Indonesia

\begin{abstract}
Puger is one of the sub-districts in Jember, Indonesia, which is famous for its beaches and rich of seafood-based products. One of its common products is Sardine. Basa Sardine Sticks is an innovative product which takes the advantages of Sardine. The purpose of food innovations is to develop the economic values of Sardine and also increase Puger society's incomes. The results of present study showed that the Basa Sardine Sticks possessed high effectiveness. This was indicated by the results of descriptive statistical analysis involving 100 respondents. The food innovation related to sticks was expected to be developed and improved for maintaining the product quality and contribute to the economy of Puger society.
\end{abstract}

Keywords- Basa Sardine Sticks, Sardine, Social Economy, Puger.

\section{INTRODUCTION}

Puger is a beach located in Jember, East Java, Indonesia. Puger is known for its natural beauty and rich of fish, especially Sardine. This beach attracts many tourists to visit for enjoying the natural scenery it offers. The most potential fish in the beach is Sardine. Sardine is a fish commodity that can be sold at a very reasonable price.

The role of the government and local communities is required to develop Puger potential. However, the local government has not managed and developed the potential, particularly the natural resources, to its utmost. This is seen from the lack of infrastructure and facilities provided by the local government. The availability of public facilities, such as toilet, is still very limited. The most important thing is to maintain the cleanliness of Puger in order to increase the interest of tourists and provide the comfortable place for commercial activities.

The promotion of Puger beach is also needed upon improving the beach in order to create comfortable conditions. The setting at shopping stalls, such as those selling souvenirs and food, is also important to take into account. It deals with the development of economic potential of Puger society. Generally, the economy in Puger primarily relates to the fishermen that exploit the sea products. Therefore, it should be expected to improve the facility available and to ensure the social and economic life in Puger.
Based on the empirical evidence and theories in the abovementioned elaboration, the present study concludes that Puger offers so much potential if it is developed optimally. This can be seen by the natural beauty of Puger and also the potential offered by the abundance of Sardine. Researchers create innovatively of Sardine food preparations as a solution to increase the value of Sardine. In addition, food innovation is expected to improve the socio-economic conditions of Puger society.

\section{LITERATURE REVIEW}

\section{General Conditions of Puger}

The village of Puger Beach is located in Puger Kulon, Puger sub-district, within $\pm 40 \mathrm{~km}$ to the south of Jember district. The village dentoes a fishing area with various uniqueness's. Puger always performs one particular ritual called "float offerings" every year. This ritual is an expression of gratitude to God Almighty for prosperity with which the society has been endowed. This beach is rich in natural resources, such as fish. The fresh fish is sold to public and there are also some products processed into condiment as well as some other processed products such as crackers, chips, and other processed dried fish. Puger marine products are also well known by the public outside the area since the fish caught in Puger are widely distributed and supplied to the surrounding areas. The most popular fish commodity in this regard is Sardine. This fish contains many nutrients beneficial for health. Sardine is marine fish species of the genus Sardinella. This fish varies in sizes, but usually the fish are packed in can. The seas in Indonesia are rich in fish, especially Sardine, mostly found in Puger. There are some cannedSardine factories which sell their products with raw materials obtained from Sardine. Sardine containsa lot of vitamins, such as for strengthening teeth, EPA (eicosapentaenoic acid) in the omega-3 to supplement the immune system and strengthen bones. Additionally, DHA (dokosaheksaenoat acid) is useful to improve intelligence. According to Suseno's (2014) research results, the oil in sardine (sardinellalongiceps) contains EPA and DHA by $21.77 \%$ amounting to $11.59 \%$. The abundance of EPA and DHA is fine potential for medicines and health products in preventing coronary heart disease. 


\section{Basa Sardine Sticks}

Basa Sardine Sticks is a processed seafood product derived from diversification. The diversification on processed seafood products is intended to increase the value of Sardine. The value of the question relates to all the processes done either manually or mechanically, which can be done by modifying the forms from the sea itself. These modifications include modifying the form, texture, and taste of seafood itself. Basa Sardine Sticks is a process of creating a new product related to customers' needs and market demand in the form of innovative and imitative product.

Aimed at developingSardine-based product, the present studystrived to produce Sticks base (Sardine sticks in various flavours). The sticks are made from Sardine raw materials. At present, the sticks processed popular in Pugersociety is processed from catfish (Handy \&Kartikawati, 2015). Thus, the researchers invent new food sticks to make use of other fish, which is Sardine. The reason for choosing Sardineas raw material for food innovation is becauseit has the potential health content and has a relatively low price. Sticks base is expected to develop the economic life ofPuger society.

\section{Basa Sardine SticksProcessing}

At this stage,the process concerning how to make the products from Sardineis elaborated. The following is the stage of making Basa Sardine Sticks.

1. Put all Sardines into prestountil they get soft and then pour the seasoning.

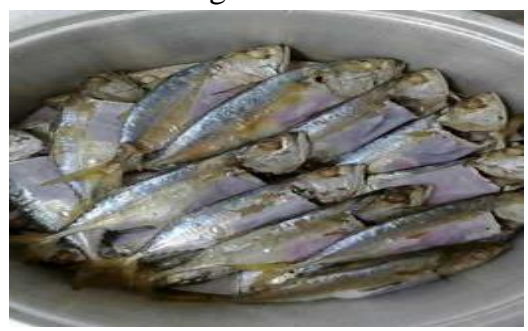

Fig.1: Sardine Already Presto

2. Mix eggs, add the spice that has been mashed, mix the baking powder, and stir them together.

3. Mix the flour and cornstarch until you get smooth texture, and then addegg and iced water.Then mould the dough until it gets smooth. After that, the dough is powdered using a grinding machine with customized size.

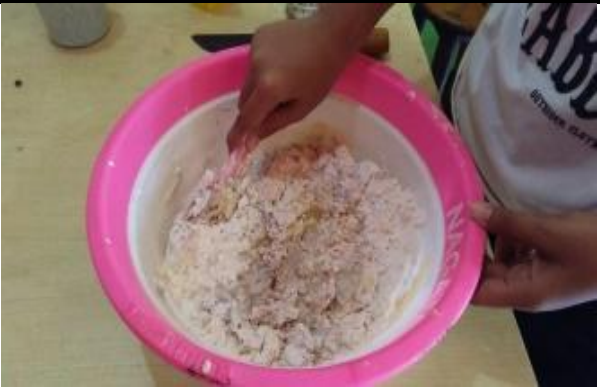

Fig.2: The batter is well-blended

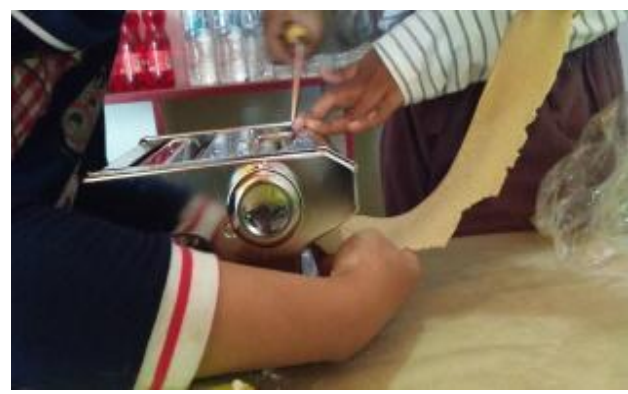

Fig.3: Grinding the batter

4. Fry the dough,afterit is cut into pieces, using a medium heat until it turns golden brown. After that, drain it and do packaging

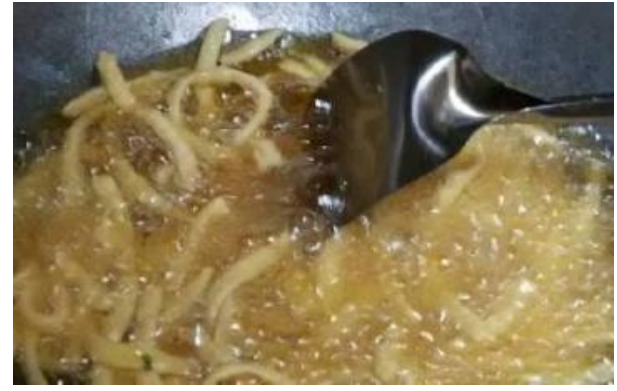

Fig.4: Stick Frying Process

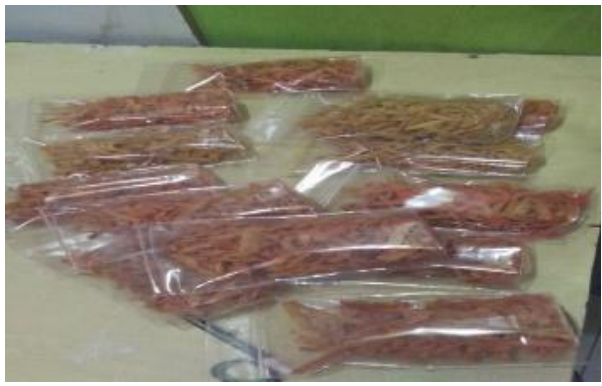

Fig.5: Packaging session

5. After all sticks are packed, then product labelling can begin. This product label serves as the product identity. 


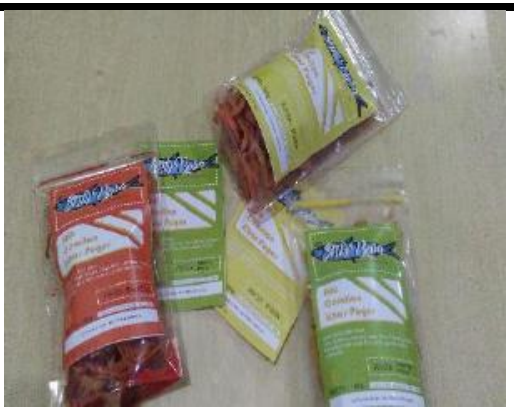

Fig.6: Product Label Stick Already Given

\section{Product Marketing}

The product manufacturing has been described in previous chapters. The last stage is the packaging products for sale. The products thathave been packaged are ready forsale. The process of product marketing is done through e-commerce, direct selling, social media, and outlet sale. The followings are the sales strategies by using multiple accesses.

1. Social Media

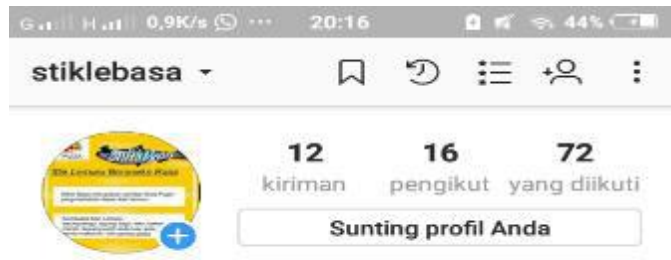

Stik Lemuru Beraneka Rasa

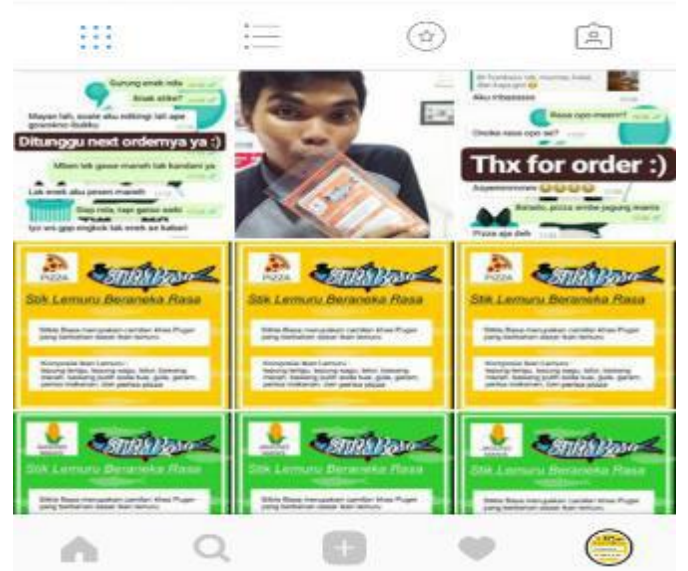

Fig.7: Instagramof Basa Sardine Sticks

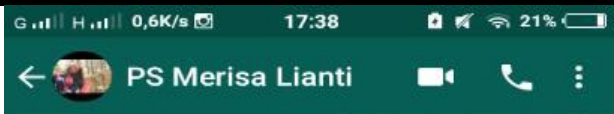

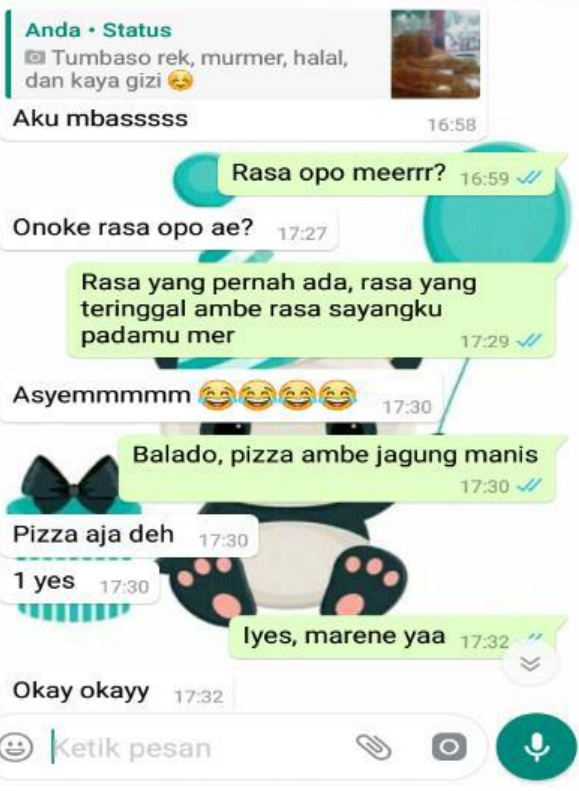

Fig.8: WhatsApp ofBasa Sardine Sticks

Sales by using social media and accounts, such as Instagram, serve to provide information relating to the products offered. The information shows the advantages of the product. It aims to attract consumers' interest to increase product sales. The various information and consumers' comments are attached onto the product package to encourage the sellers and the buyers in improving the products as well as satisfactory services.

2. E-Commerce

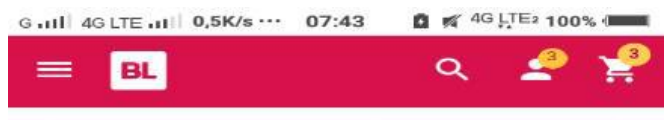

stikle basa stik lemuru beraneka stikle basa stik lemuru stil

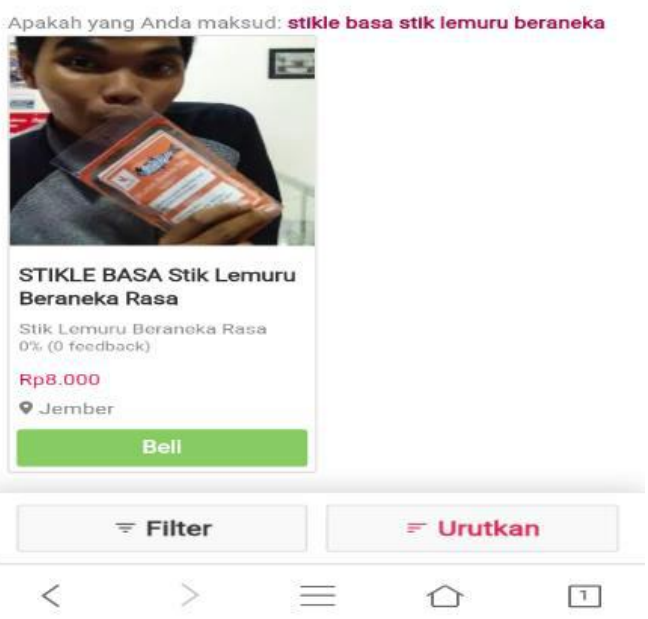

Fig.9: Sales Through Stalls Open Page 
Product promotion is also done through the e-Commerce. The sales process is doneby utilizing bukalapak.com. This account aims to promote products through online promotion. It provides many benefits for the seller since the sale can be done anytime and anywhere. Besides,ecommerce can overcome the obstacles of buying and selling due to distances.

\section{Direct Selling and opening sales stand}

Sales stand was also opened at bazar and car-free-day events to increase sales and gain many consumers.

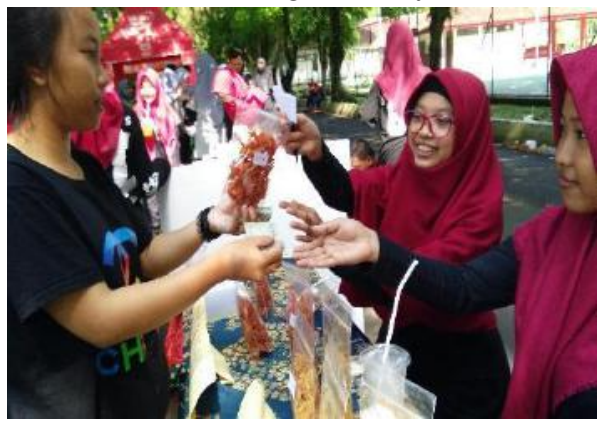

Fig.10: Sales Events Bazar

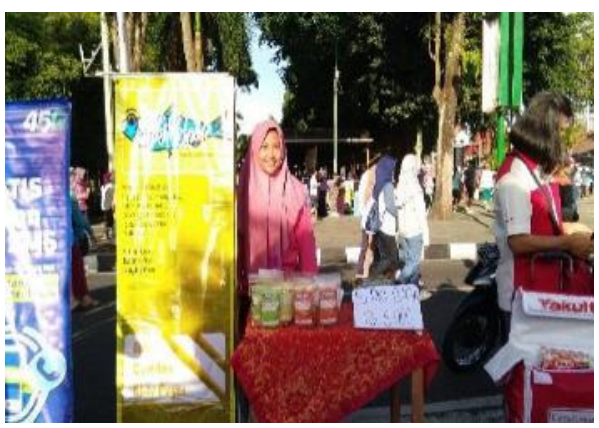

Fig.11: Sales and car-free day

\section{Product Projection}

Product projection is a production plan developed by product developers toachieve high sales value by maintaining economic principles in it. At the moment, the resulting product has the basic ingredients using Sardine, which is abundantly available in the market as well as in the local area.

Sardine (SardinellaSardine)is a species ofActinopterygii in the genus of Sardinella. These fish are found in the waters of Bali Strait. This fish has many names such as:sement or sempenit currently still in a small fish. If the fish is an adult, the size is about 12 cmcalled Protolan. When the size is about $15 \mathrm{~cm}$, it is called Sardine, and when the size is bigger the former, it iscalled Sardine Cat. Sardine oilis used as a local product in Indonesia. The most famous sardine is Japanese sardine (Sardinellamelanostica).Since Sardine is unfamiliar, a more famous label,canned sardines, is preferred. Actually, Indonesia has some types of Sardine, such as sardinellalongiceps, sardinella SIRM, sardinellaleigaster, and sardinellaclupeoides. These names are derived from thousands of islands, especially Pekalongan, Tegal, and Pelabuhan Ratu. However, most Sardines are foundin Bali Strait. Sardine Basa Sardine Sticksis processed into the snack. Since, it is cheap and has many nutrients.

\section{Product Superiority}

Basa Sardine Sticks has several advantages in it, includingabundance ofnutrients, reasonable price, and long storage-period. This is due to the processing that is done manually by the manufacturer in order to preserve the products' cleanliness and hygiene. Basa Sardine Sticks has several different flavours, such ad spicy, roasted corn, and pizza.

Basa Sardine Sticks comes with hands-on packaging, so customer should notworry about the product beingwrecked at any time. These products also offer longerexpiration period. Sticks Sardine isrich in nutrients and available at reasonable price thatcan be consumed by all people, children, and adults.

\section{Products Weaknesses}

Despite their strengths, the products have some weaknesses. Particularly,they deal with the limitated number of labourers, resulting in low production volume.In addition, the lack of promotion also contributes to the issues at hand. However, these problems can be overcome by adding labourers

\section{METHODS}

This study employed quantitative research that emphasized on numerical data using statistical methods (Anwar, 2007:5). Subhana and Sudrajat (2005:25) state that quantitative research, in terms of objectives, is applied to test a theory, present a fact, describe the statistics, show the relationship between variables and some developing concepts, develop an understanding, and describe many things.

Quantitative research method can be interpreted as a research method that is based on the philosophy of positivism, which is used to examine the population or a particular sample. The sampling technique is random sampling. Data were collected by using research instruments. Quantitative data analysis/statistics aimed to test the hypothesis previously set. Burns and Bush state (in Mangkunagara, 2011) that the quantitative research is research required the use of the structure of a question where the answer choices provided and require many respondents. The number of samples in this study is 100 respondents using random sampling techniques.

Data collection techniques can be done by questionnaire, interview, observation, and the combination of all three 
(Sugiyono, 2011: 137). Additionally, Sutopo (1988) states that the data collection techniques are grouped into two basic ways that interactive method included observation and interviews as well as non-interactive of documentation. The data collection aims to obtain data related to the research. Data collection instruments used in this study was the questionnaire. Sugiyono (2011) stated that the questionnaire is a technique of data collection thatis done by giving a set of questions or written questions to the respondent to answer. The data collection Techniques were done by spreading questionnaireformthat contains questions. Effectiveness Sticks include assessment base (Stick Sardine in Various Flavours) on a Community Economic Social ofPuger.

Moreover, the use of the questionnaire is to obtain information needed to support the research. The questionnaire used was a questionnaire using Likert Scale models. Likert scale in the questionnaire is in range of five points covering Very Poor, Poor, Fair, Good and Very Good.

\section{RESULTS AND DISCUSSION}

The following section points out the results on assessing the effectiveness of Sticks product. In the initial phase, the description of the sample respondentsis presented. This following table is the information on the respondents.

Based on the previous data, it shows that the number of data is 38 men. It indicates the number of male is lower than female totalling 62 people. Data respondents aged 015 years were 10 respondents, aged $16-25$ years are 71 respondents, and aged 25 years and beyond amounted to 19 respondents. This shows the highest number of respondents aged 16-25 years. Respondents aged 16-25 years are those studying at secondary schools and higher education environment. The table also shows that $64 \%$ of respondents are not involved in business or other entrepreneurial activities. This shows that their awareness of entrepreneurship is still very low.

Table.1: Respondents Description

\begin{tabular}{llll}
\hline Demographics & & $\begin{array}{l}\text { Freque } \\
\text { ncy }\end{array}$ & $\begin{array}{l}\text { Perce } \\
\text { ntage }\end{array}$ \\
\hline Gender & Male & 38 & 38.0 \\
& Female & 62 & 62.0 \\
\cline { 1 - 2 } Age & Age 0-15 years & 10 & 10.0 \\
& Age 16-25 years & 71 & 71.0 \\
& Age 25 years & 19 & 19.0 \\
& and over & & \\
\hline Ownership & No & 64 & 64.0 \\
& Yes & 36 & 36.0 \\
\hline & Total & 100 & 100.0 \\
\hline
\end{tabular}

The next discussion is concerned with the study of the effectiveness of the products acquired Sticks base (Stick Sardine of Various Flavors) on the Community Economic Social of Puger using quantitative data involving 100 samples. The result was obtained through the questionnaires that have been designed based on the effectiveness of product development. The references are interpreted from Nunnally in (Praise \&Razaq, 2016)

Table.2: Mean Values Interpretation

\begin{tabular}{ll}
\hline Mean & Interpretation \\
\hline 1.00 to 2.00 & Low \\
2.01 to 3.00 & Medium \\
3.01 to 4.00 & Medium-Good \\
$4,01-5.00$ & Good \\
\hline
\end{tabular}

Table.3: Effectiveness ofBasa Sticks Product

\begin{tabular}{clllllll}
\hline No. & Item & $\mathrm{N}$ & Minimum & Maximum & Mean & $\begin{array}{l}\text { Std. } \\
\text { Deviation }\end{array}$ & Interpretation \\
\hline 1 & Suitability colour logo & 100 & 2.00 & 5.00 & 3.99 & 0.78 & Medium-Good \\
2 & Conformity animation of & 100 & 3.00 & 5.00 & 4.26 & 0.69 & Good \\
3 & Packaging products & 100 & 2,00 & 5,00 & 4.10 & 0.74 & Good \\
4 & DiversityTaste & 100 & 2.00 & 5.00 & 3.72 & 0.98 & Medium-Good \\
5 & salty Taste & 100 & 2.00 & 5.00 & 4.15 & 0.77 & Good \\
6 & crispy texture & 100 & 2.00 & 5.00 & 4.18 & 0.77 & Good \\
7 & protein & 100 & 3.00 & 5.00 & 4.11 & 0.66 & Good \\
8 & the content of DHA & 100 & 3.00 & 5.00 & 4.14 & 0.68 & Good \\
9 & Vitamin & 100 & 300 & 5.00 & 4.07 & 0.67 & Good \\
10 & Price & 100 & 3.00 & 3.00 & 4.49 & 3.16 & Good \\
11 & Flexibility obtain product & 100 & 2.00 & 5.00 & 4.77 & 5.13 & Good \\
12 & Effectiveness of the economic & 100 & 2,00 & 5,00 & 4,40 & 0,81 & Good \\
& value of the market & & & & & & \\
& Total & 100 & 2.00 & 5,00 & 4.20 & 1.32 & Good \\
\hline
\end{tabular}


The table on the mean of the effectiveness of the product shows that the base sticks reach the highest mean of 4.77 at point 11 about the flexibility to get the product sticks. It can be concluded that the product can be sold easily, so consumers can consume itevery time. This is certainly an advantage for Basa Sticks product related to the ability of the product developer in doing promotions employing fine technique.

On the other hand, the lowest value was evident on the point four on the diversity of flavours. This point was evaluated on the diversity of flavours of Basa Sardine Sticks with a mean of 3.72. This was because Basa Sardine Sticks had only three variants, including Spicy, pizza and sweet corn. To overcome this problem, addingnew variants and diversity of Basa Sardine Sticks is required.

\section{CONCLUSION}

Puger is one of the waters territorial that is rich in fish. One of the potential economic fish is Sardine. Sardine is a type of fish that is widely used as food cans. Sticks Innovation Basa is a food processing that becomes an alternative to increase the value and help the economy society in Puger. Based on the analysis, it has been developedthat this product has a good effectiveness. However, these products still have many shortcomings that needed to be better evaluation in order to improve the product quality.

\section{SUGGESTION}

Basa Sticks can be regarded as a breakthrough in harnessing the potential of Sardine. This product is still very far from being perfect. Suggestions for the next research are to find new forms of food processing by replacing the raw materials available. This is certainly also needed to be considered on the social conditions and the availability of material.

\section{REFERENCES}

[1] Azwar. (2007). Research methods. Yogyakarta: Student Library

[2] Bungin, B. (2005). Methodology Penelitian Kuantitatif Communications, Economics, and Public Policy And Other Social Sciences. Jakarta: Prenada Media

[3] Puji, RPN, and Razaq, A. (2016). Learning Style of MBTI Personality Types in History Learning at Higher Education, 3 (6), 289-295

[4] Subhana, M. and Sudrajat. (2005). Basic Scientific Research. Bandung: Pustaka Setia

[5] Sugiyono, (2011).Educational Research Methods (Quantitative Approach, Qualitative and R \& D).Bandung: Alfabeta. 